\title{
The Consequences of School Dropout in the Kadey Division; East Region of Cameroon
}

\author{
Maurice Wedjou Ndjouma
}

ICT University

\begin{abstract}
The agenda for sustainable development 2030 has been established and approved by the general assembly of the United Nations in2015. This agenda includes 17 goals adopted by several countries to promote the development of local communities by tackling and reducing the consequences of school dropout. The continent of Africa through the agenda 2063 endorses different aspirations that have to be met by the year 2063 to minimize the consequences of school dropout, which would lead to a peaceful and protected Africa. The Cameroon Vision 2035 also defined a practical vision of long-term development in the country of Cameroon founded on the eradication of the consequences of school dropout. However, school dropout remains a reality worldwide and generates several consequences which drastically impact the lives of people. It is on this evidence that this research work aimed at exploring the consequences of school dropout in the Kadey Division, East Region of Cameroon. This study refers to the qualitative research method using the subjectivism ontology and the inductive approach. The epistemology is interpretivism and the axiology is value-bias. The research also employs interviews as the sampling strategy, and 20 respondents gathered in 4focus groups representing the educational stakeholders of the Kadey Division have volunteered to participate in these interviews. Data were analyzed through the various coding of the grounded theory including open coding, axial coding, and selective coding. The social, education, and economic consequences of school dropout were identified as well. Parents and educators mustacknowledge that school failure has this particularity that it penalizes a child for the rest of his life. Any student who stops hisstudies before having completed his secondary school or vocational training has fewer opportunities to grow within the society. This study recommends that the community stakeholders in the Kadey Division, East region of Cameroon must work collaboratively on minimizing the consequences of school dropout to contribute to the sustainable development of this locality
\end{abstract}

\section{Key Worlds: School dropouts, Education for All}

\subsection{Introduction}

The agenda for sustainable development 2030 includes several goals such as no poverty, zero hunger, good health and well-being, quality education, gender equality, clean water and sanitation, affordable and clean energy, decent work and economic growth, inequality reduction, industry, innovation and infrastructure, sustainable cities and communities, responsible consumption and production, climate action, life below water, life on land, peace and justice, strong institutions (United Nation, 2015). These goals are very useful and important for the development of any community around the world. However, the goal related to "quality education" and "No Poverty" is very relevant for this research work; as it stipulates that; by the year 2030, all children must complete free, impartial, and quality primary as well as secondary education; also all students should obtain the knowledge and skills required to support the sustainable development which would promote education for all and therefore minimize the consequence of school dropout (United Nation, 2015). Also, it is relevant to mention that the country of Cameroon is a signatory of several conventions with various international organizations for the education of all; which would reduce the phenomenon of school dropout and its consequences; yet the consequences of school dropout in the Kadey Division, East Region of 
Cameroon remain problematic as the rate of school dropout is very high compared to other division in Cameroon as shown on the table below.

Table 1: Summary of School Attendance and School Dropout Kadey Division 2016-2020

\begin{tabular}{|l|l|l|l|l|}
\hline Academic School Year & TBS & TES & TSDR & PSDR \\
\hline $2016-2017$ & 10871 & 8801 & 2070 & $19 \%$ \\
\hline $2017-2018$ & 10461 & 7838 & 2623 & $25 \%$ \\
\hline $2018-2019$ & 9969 & 6758 & 3211 & $32 \%$ \\
\hline $2019-2020$ & 10389 & 6059 & 4330 & $42 \%$ \\
\hline
\end{tabular}

Source: (Ministry of Education: Kadey Divisional Education, 2021)

Figure 1: School Attendance and School Dropout Kadey Division 2016-2020

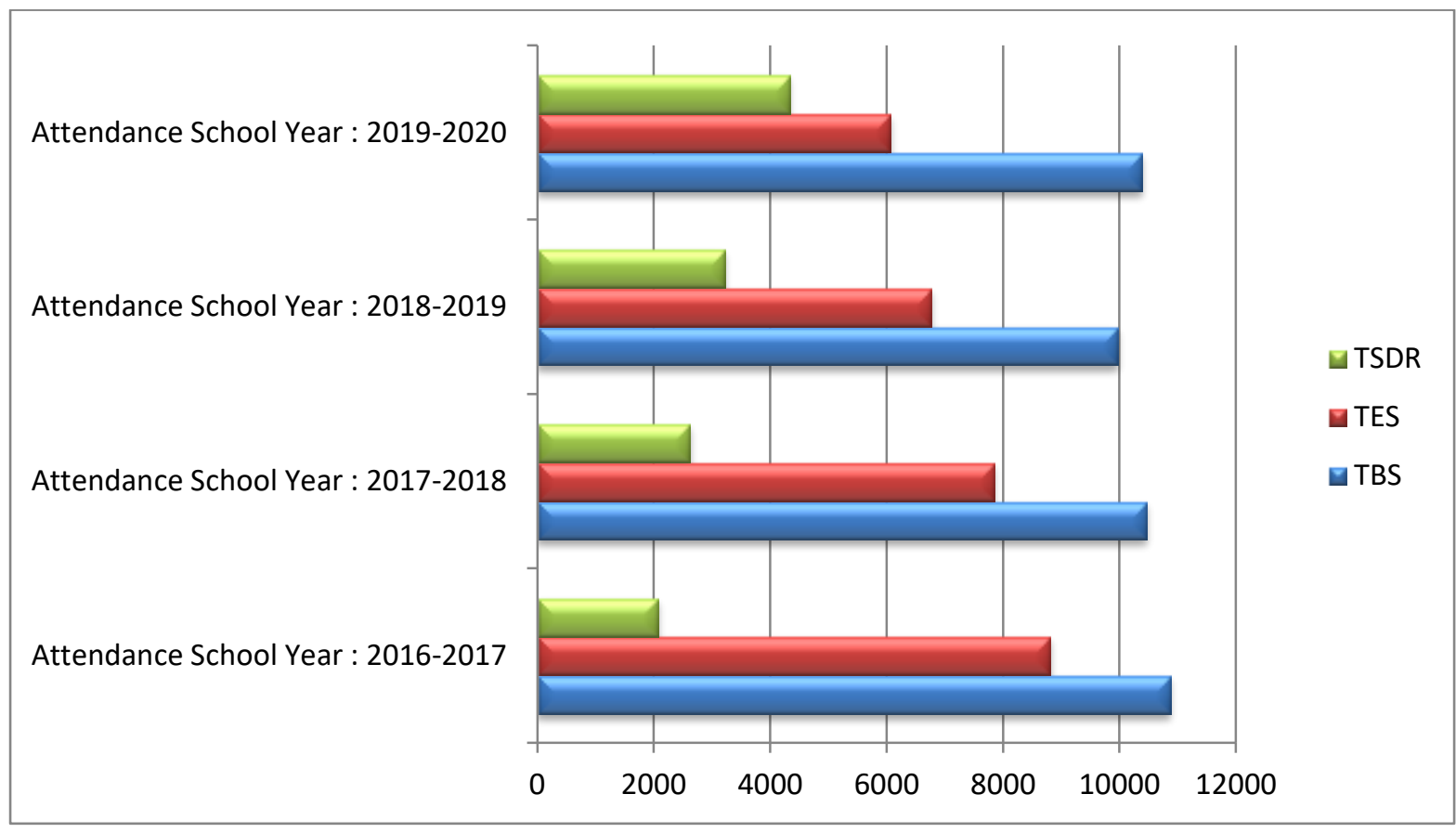

Source: (Ministry of Education: Kadey Divisional Education, 2021)

BS: Number of Students Enrolled at the Beginning of School Year

ES: Number of Students at the End of the School Year

TBS: Total Number of Students Attendance Beginning of School Year all Sections

TES: Total Number of Students Attendance End of School Year all Sections

TSDR: Total Number of Students Drop out at the End of School Year

PSDR: Percentage of School Dropout.

\subsection{Literature Review}

This study discussed two essential key concepts including School Dropout and Education for all. School Dropout refers to stepping out of school without completing a well-defined sequence of study. (López, Opertti, \& Vargas Tamez, 2019). While Education for All discusses specific policies, which provide the school with a clear meaning of the term inclusive education and its consequences (Victoria State Government, 2019). These two terms stated above are supported by the Distributed Leadership Theory and Freud's Theory. These theories emphasize the consequences of school dropout as elaborated in this research.

\subsection{The distributed leadership Theory}


The distributed leadership theory appears to be widely expanded in the 21 st century. Gronn (2010) mentioned that several scholarly publications bent on the distributed leadership theory since 2000. Alma Harris (2002) argued that the distributed leadership theory engages proficiency within the institution, instead of just looking for this merely through official position. Jacky Lumby (2002) emphasizes the implementation of this theory within the education area by sharing responsibilities among educational staff. The distributed leadership theory refers to the team leadership theory or the democratic leadership theory. The theory focuses on leadership action and practice instead of apparent leadership roles. These leadership practices happen when the authoritative leaders, as well as those holding the subordinate positions, collaborate and interact with each other. Through the distributed leadership theories, tasks are shared between numerous staff members; thus, allowing these different levels of leadership to examine the consequences linked to certain derivatives of educational sectors such as school dropout (Chuck, 2019). It is critical to interact with available community organizations and partners including the adolescence-serving institutions, mental health organizations, social services structures, and educational organizations to reach and meet consensus, institute priorities, and promote action planning about dropout prevention. (Charmaraman \& Georgia, 2012). The distributed leadership theory emphasizes the relevance of networking with several sectors of the local, national and worldwide community to fix, solve and regulate educational issues, which is pertinent for this research work.

\section{Freud's Theory}

Freud's theory is premised on psychology; Freud initiated the psychoanalysis theory which generally is considered as a theory of personality (Rucks, 2015). Freud's theory focuses on the human personality and how it is constructed. Freud establishes that personality is mainly established before the age of 5 years, according to the experiences lived by the children (Cherry K. , 2019). These experiences impact deeply the development of the personality of students and may influence their motivations for learning. This theory is relevant for this research work as it may explain the consequences of school dropout in the Kadey division due to low school attendance. Freud's theory displays 3 dimensions namely the superego, the ego, and the Id. The superego represents how an individual views society at a moral and social level with a strong focus on human basic needs satisfaction. (Cherry K. , 2019). This is relevant for this work as Freud's theory emphasizes the basics of human needs which are essential for the student's achievement and mitigate the consequence of certain phenomenon such as school dropout (Cherry K. , 2019). Students leaving school early is the same as building a giant wall between these learners and their future which would have symbolized or represented the expression of the students' potential and achieving the childhood reveries or dreams (Dekkers \& Claassen, 2001).

\subsection{Methodology}

The research method of this work is qualitative (Patton M. Q., 2015); which is based on words, feelings, emotions, thoughts, and other non-numerical and unquantifiable elements involving the consequences of school dropout in the Kadey Division, East Region of Cameroon. The sampling strategy is an interview of (20) respondents divided into 4 major clusters representing the educational stakeholders of this locality. The research work employs different data analysis techniques including open coding, axial coding, selective coding, theoretical saturation, and the modelling of the framework. (Glaser \& Strauss, 1967). The research approach is inductive (Glaser \& Strauss, 1967); the ontology is subjectivism with the axiology value-bias. The 10 key points for ethical considerations (Bryman \& Emma, 2011) were observed throughout the research work. Results are checked through internal and external validity (Polit \& Hungler , 1995). These include transferability, credibility, conformability, and dependability (Polit \& Hungler, 1995).

\subsection{Data Analysis and Presentation of Results}

This section exhibits the inspection of thoughts and stories of participants into codes concerning the consequences of school dropouts in the Kadey Division as shown below.

Table 2: Open Coding and Theoretical Saturation for the consequences of School Dropout

\begin{tabular}{|l|l|l|l|}
\hline FG & Categories & Abbr & Narratives /Codes/ Opinions \\
\hline $\mathbf{1}$ & Social & SOC & $\begin{array}{l}{[\ldots] \text { The rural area of Batouri remains heavily underdeveloped as }} \\
\text { well as the family. }\end{array}$ \\
\hline
\end{tabular}




\begin{tabular}{|c|c|c|c|}
\hline & Education & EDU & $\begin{array}{l}{[\ldots] \text { The rate of literacy is very important. Many people in rural }} \\
\text { areas cannot read nor write one of the official languages. }\end{array}$ \\
\hline & Education & EDU & $\begin{array}{l}{[\ldots] \text { The minorities (Baka and Bororo) are very illiterate; very few }} \\
\text { of them hold } \\
\text { a primary school certificate }\end{array}$ \\
\hline & Social & SOC & $\begin{array}{l}{[\ldots] \text { Young people are getting more involved in prostitution, the use }} \\
\text { of drogue, alcoholism, and vandalism. }\end{array}$ \\
\hline & Economic & ECO & $\begin{array}{l}{[\ldots] \text { The lack of qualified or trained people to hold decent }} \\
\text { employment or job within the companies present in the areas. }\end{array}$ \\
\hline \multirow[t]{3}{*}{2} & Social & SOC & $\begin{array}{l}{[\ldots] \text { The percentage of unwanted pregnancies is becoming }} \\
\text { important. }\end{array}$ \\
\hline & Educ & EDU & $\begin{array}{l}{[\ldots] \text { The underdevelopment of the people in terms of their }} \\
\text { intellectual abilities. }\end{array}$ \\
\hline & Economic & ECO & $\begin{array}{l}{[\ldots] \text { Unemployment is very high among young people in the Kadey }} \\
\text { division. }\end{array}$ \\
\hline \multirow[t]{7}{*}{3} & Social & SOC & {$[\ldots]$ Many teenagers are becoming parents. } \\
\hline & Educ & EDU & $\begin{array}{l}{[\ldots] \text { Education is not a priority for most parents from the rural areas }} \\
\text { of Batouri and they are not motivated to invest money to push their } \\
\text { children far to school }\end{array}$ \\
\hline & Eco & ECO & $\begin{array}{l}{[\ldots] \text { Native workers from the Kadey Division hold positions as }} \\
\text { manoeuvres } \\
\text { within the companies with no possibility to climb to better } \\
\text { positions. }\end{array}$ \\
\hline & Social & SOC & $\begin{array}{l}{[\ldots] \text { The proliferation of sexual diseases of AIDS and other sexual }} \\
\text { diseases. }\end{array}$ \\
\hline & Social & SOC & $\begin{array}{l}{[\ldots] \text { The underdevelopment of the area in terms of social }} \\
\text { infrastructure } \\
\text { (roads, hospitals, markets, and others). }\end{array}$ \\
\hline & Economic & ECO & $\begin{array}{l}{[\ldots] \text { Native workers from the rural areas of Batouri receive the }} \\
\text { very lowest incomes of companies. }\end{array}$ \\
\hline & Education & EDU & $\begin{array}{l}{[\ldots] \text { School establishments from the Kadey Division lose }} \\
\text { their pupils in favor of other activities. }\end{array}$ \\
\hline
\end{tabular}

\section{Source: Field notes (2021)}

Looking at the table above, three major categories of consequence were identified resulting from the issue of school dropout in the Kadey Division of Batouri, East region of Cameroon. These consequences include social, education, and economic. These categories are further regrouped as shown in the axial coding process below.

\section{Table 3: Axial Coding for the Consequences of School Dropouts}

\begin{tabular}{|c|c|c|}
\hline Questions & Categories & Narratives / Descriptions / Codes \\
\hline \multirow[t]{2}{*}{$\begin{array}{l}\text { What are the } \\
\text { consequences of } \\
\text { school dropout in the } \\
\text { rural areas of Batouri, } \\
\text { East Region of } \\
\text { Cameroon? }\end{array}$} & Social & $\begin{array}{l}{[\ldots] \text { The rural area of Batouri remains heavily underdeveloped }} \\
\text { as well as the family. } \\
{[\ldots] \text { Young people are getting more involved in prostitution, the }} \\
\text { use of drogue, alcoholism, and vandalism. } \\
{[\ldots] \text { The percentage of unwanted pregnancies is becoming }} \\
\text { important. } \\
{[\ldots] \text { Many teenagers are becoming parents. }} \\
{[\ldots] \text { The proliferation of AIDS and other sexual diseases. }} \\
{[\ldots] \text { The underdevelopment of the area in terms of social }} \\
\text { infrastructure (roads, hospitals, markets, and others). }\end{array}$ \\
\hline & Education & [...] The rate of literacy is very important. Many people in the \\
\hline
\end{tabular}




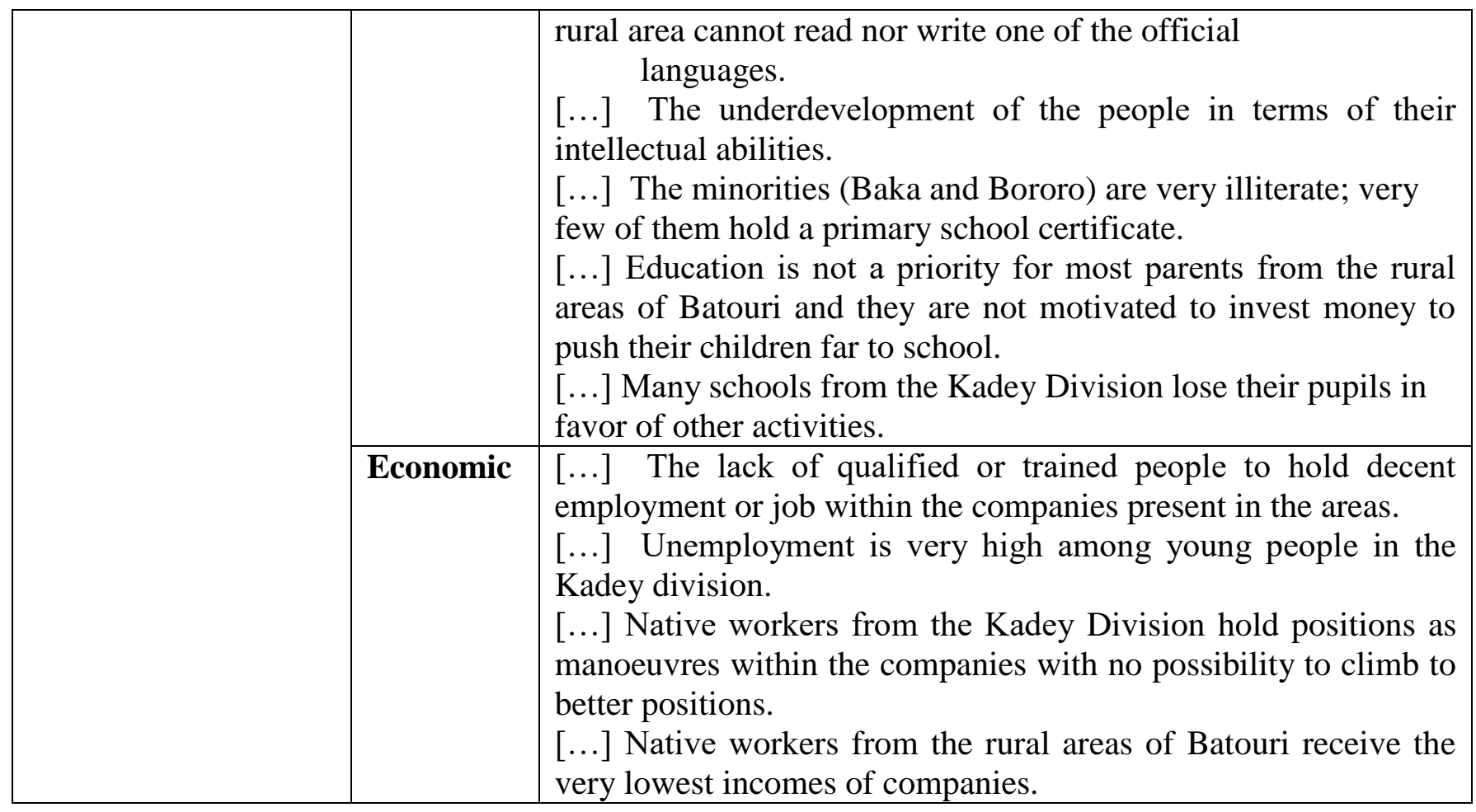

Source: Field Data (2021)

\section{Memo:}

I. Social Impact: The rural areas of Batouri are lacking social infrastructures such as decent schools, hospitals, roads, and others. Unwanted pregnancies, prostitution, the use of drogue and alcoholism are dramatically impacting the population of these rural areas including children and teenagers.

II. Education Impact: The rate of literacy is very high in the Kadey division; many parents are not able to neither write nor read one of the official languages including French and English. Very few minorities' people including the Baka and Bororo hold a primary school certificate.

III. Economic Impact: Natives from the rural areas of Batouri are facing difficulty getting decent jobs in the companies as they are not qualified and trained. Most of the time they hold positions as manoeuvres with very low incomes.

Table 4: Selective Coding for the Consequences of School Dropout

\begin{tabular}{|c|c|c|c|}
\hline Questions & Categories & Narratives/ Descriptions & RK \\
\hline \multirow[t]{3}{*}{$\begin{array}{l}\text { What are the } \\
\text { consequences of school } \\
\text { dropout in the rural } \\
\text { areas of Batouri, East } \\
\text { Region of Cameroon? }\end{array}$} & Social & $\begin{array}{l}{[\ldots] \text { The rural area of Batouri remains heavily }} \\
\text { underdeveloped as well as the family; young people are } \\
\text { getting more involved in prostitution, the use of drogue, } \\
\text { alcoholism, and vandalism.; the percentage of unwanted } \\
\text { pregnancy is becoming important among teenagers; the } \\
\text { proliferation of AIDS and other sexual diseases; the } \\
\text { underdevelopment of the area in terms of social } \\
\text { infrastructures (roads, hospitals, markets, and others). }\end{array}$ & 6 \\
\hline & Education & $\begin{array}{l}\text { [...] The rate of literacy is very important. Many people in } \\
\text { the rural area cannot read nor write one of the official } \\
\text { languages; the minorities (Baka and Bororo) are very } \\
\text { illiterate; very few of them hold a primary school certificate; } \\
\text { education is not a priority for most parents from the rural } \\
\text { areas of Batouri and they are not motivated to invest money } \\
\text { to push their children far to school; many schools from the } \\
\text { Kadey Division lost their students in favor of other activities. }\end{array}$ & 5 \\
\hline & Economic & [...] The lack of qualified or trained people to hold decent & 4 \\
\hline
\end{tabular}




\begin{tabular}{|l|l|l|}
\hline & $\begin{array}{l}\text { employment or job within the companies present in the } \\
\text { areas; native workers from the Kadey Division hold } \\
\text { positions as manoeuvres within the companies; they receive } \\
\text { the lowest income with no possibility to climb better } \\
\text { positions. }\end{array}$ \\
\hline
\end{tabular}

\section{Source: Field Data (2021)}

Figure 2: Modelling a framework for consequences of school dropout

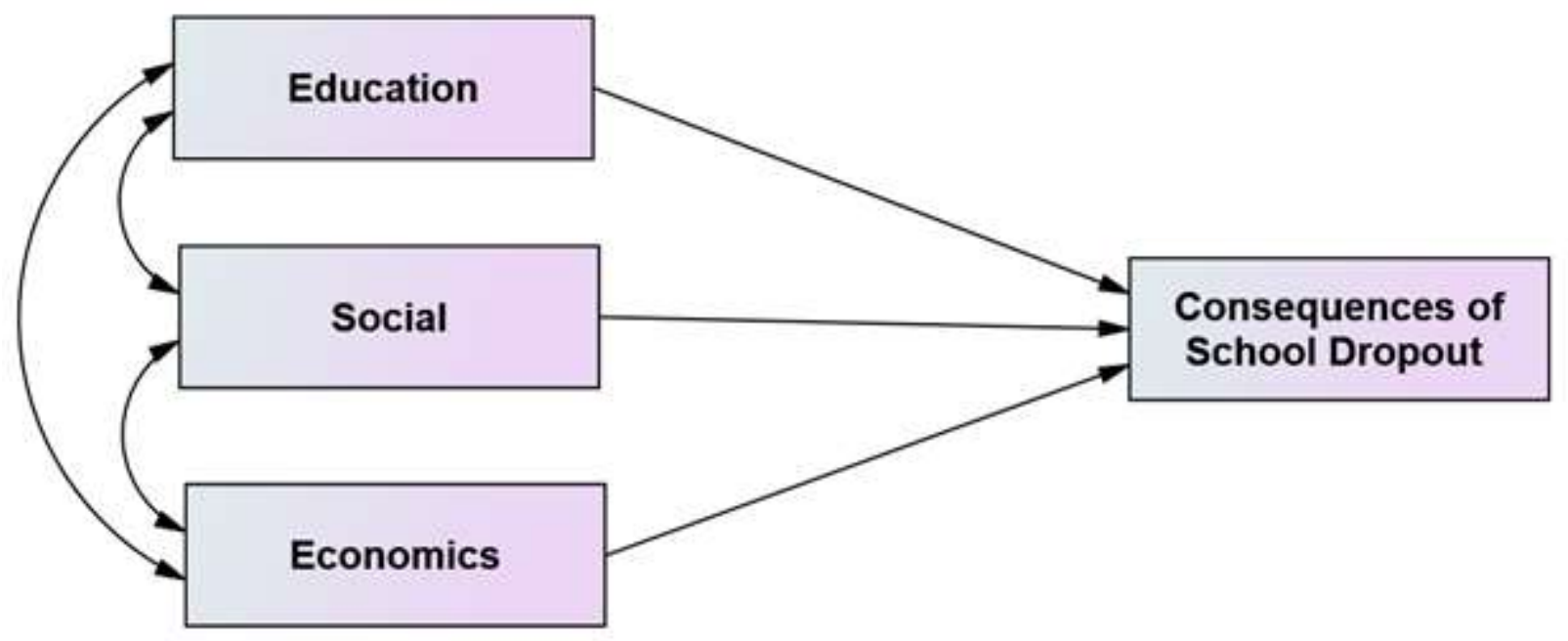

The figure shown above displays how much the consequences of school dropouts are affecting the local community of Batouri. The above model indicates that the consequences of school dropout are deeply impacting the social, education, and economic milieu of the Kadey Division, East Region of Cameroon.

\subsection{Discussions and Conclusion}

Through the analysis of the data, several consequences of school dropout have been highlighted including the education, social and economic elements. The analysis also shows that the major consequence of school dropout in the Kadey division affects deeply the social environment; the locality of the Kadey Division remains strongly enclaved with several social ills such as unemployment, prostitution, banditry, crime, the sale of human bones, and drug abuse by young people. Dufort \& Eaker (2016) mentioned that education not only opens the door economically, and also the quality of life, health, and longevity are strictly linked to the good social comfort of a community. The social facet of sustainable growth, which involves social inclusion, appears to be predominantly significant for several countries in Sub-Sahara Africa including Malawi, Burundi, the Democratic Republic of the Congo, Tchad, Niger, and Central African Republic (Bartniczak \& Raszkowski, 2018). Minimizing the consequences of School Dropout in the Kadey Division, the East Region of Cameroon would duplicate the implementation of the 5 aspirations of the agenda 2063 which include a wealthy Africa relying on inclusive development, sustainable growth, and the renaissance of the continent of Africa through pan-Africanism principles (African Union Commission, 2015).

\section{Reference}

1. African Union Commission. (2015). Agenda 2063: The Africa We Want. Addis-Abeba: African Union Commission.

2. Bartniczak, B., \& Raszkowski, A. (2018). Sustainable Development in African Countries:An Indicator-Based Approach and Recommendations for the Future. MDPI.

3. Bryman, A., \& Bell, E. (2015). Business Research Methods (4th edition ed.). Oxford University Press.

4. Charmaraman, L., \& Georgia, G. (2012). School dropout prevention: What arts-based community and out-of-school-time programs can contribute. National Center for Biotechnology Information, U.S. National Library of Medicine. doi:10.1002/yd.416 
5. Cherry, K. (2019). Freud's Psychosexual Stages of Development. Verywellmind. Retrieved from https://www.verywellmind.com/freuds-stages-of-psychosexual-development-2795962

6. Chuck, R. (2019, May 17). Principles of the Distributed Leadership Theory. The classroom. Retrieved from https://www.theclassroom.com/principles-distributed-leadership-theory8428458.html

7. Dekkers, H., \& Claassen, A. (2001). Dropouts, disadvantaged by definition? A study of the perspective of very early school leavers. Studies In Educational Evaluation. DOI:DOI: 10.1016/S0191-491X(01)00034-7

8. Dufort, R., Dufort, R., \& Eaker, R. (2016). Professional learning Communities at work. USA: Solution Trees Press.

9. Glaser, B. a., \& Strauss, A. (1967). The Discovery of Grounded Theory. Chicago: Aldine. . Aldine.

10. Gronn, P. (2010). Where to next for educational leadership? The Principles of Educational Leadership and Management.

11. Harris, A. (2002). Effective leadership in schools facing challenging contexts. School Leadership \& Management.

12. López, N., Opertti, R., \& Vargas Tamez, C. (2019). Youth and changing realities: rethinking secondary education in Latin America. Dropping out. Retrieved September 2019, from https://en.wikipedia.org/wiki/Dropping_out

13. Lumby, j. (2002). The management of sixth form colleges: implications for leadership. Educationline. Retrieved from http://www.leeds.ac.uk/bei/Education-line/browse/all_items/125244.html

14. Ministry of Education: Kadey Divisional Education. (2021). School Dropout in the Kadey Division. Batouri: Kadey Divisional Education.

15. Ministry of Economy, Planning and Regional Development (2019). Cameroon Vision 2035 Yaoundé.

16. Patton, M. Q. (2015). Qualitative Research and Evaluation Methods. SAGE Publications, Inc.

17. Polit, D. F., \& Hungler, B. P. (1995). Nursing Research: Principles and Methods. Philadelphia : JB Lippincott.

18. Rucks, E. (2015). Sigmund Freud's Theories of Personality.

19. United Nations General Assembly. (2015). The Sustainable Development Goals (SDGs). United $\begin{array}{lllll}\text { Nations. } & \text { Retrieved } & \text { September } & \text { 2019, }\end{array}$ https://www.un.org/sustainabledevelopment/sustainable-development-goals/

20. Victoria State Government. (2019). Education for All. Education and Training. 
